ARTICLES 


\title{
THE TERRITORIAL AND ECONOMIC EXPANSION OF THE CROWN OF ARAGÓN IN ROMANIA, AND VENETIAN RESPONSE TO CATALAN DOMINATION OF ATHENS, 1311-1331
}

\author{
Senén A. García
}

In 1311, barely a decade after the end of the Sicilian Wars (1302), a mercenary army from the Kingdom of Aragón conquered the Angevine Duchy of Athens. While seemingly representative of the inherent instability of all the Crusader kingdoms in the Eastern Mediterranean world, the events of 1311 marked the upset of the existing status quo and the general balance of power that had been painfully devised in the region after the Fourth Crusade of 1204. Though notably affecting the Angevine aspirations within European politics at the time, the takeover of Athens by the Catalan Company primarily disturbed the mercantilist interests of a quieter but unrivaled power in the region, Venice.

Within North American Medieval scholarship, with its Romantic overtones, the struggles and conflicts among the true Medieval (that is, Mediterranean) powers have been degraded to a secondary level in the accounting of Western European history. Not surprisingly then, an event of the magnitude of the Catalan takeover of Athens has remained hardly untouched by historians in the West. Aside from Kenneth M. Setton and a few other scholars', the fact that Athens once belonged to the Catalans for over seven decades has been regarded by most Medieval historians as an unrelated and ineffectual occurrence within the great evolution of western Europe.

Nonetheless, it is my conviction that the events of 1311 , aside from deserving our interest and attention for their own sake, characterize a general expansionist trend among Southern European societies, that outright demanded the occupation of coastal areas and cities as the safest mechanism

1 Among the scant number of works on Catalan Athens written by North American historians, Kenneth M. Setton's Catalan Domination of Athens, 1311-1318, (Cambridge: 1948), remains the only in-depth study on this subject, though it was first published over forty years ago. 
to safeguard their trading routes. Consequently, these emporia, while providing havens to merchant galleys, also permited commercial activities with the unoccupied hinterlands ${ }^{2}$. However, this policy could easily bring any given pair of powers into open conflict and antagonism, especially when one of them saw the other as intruding in their own «spacen. Essentially, the conflict that ensued between Venice and the Catalans in Athens after 1311 resulted from this zero-sum equational mentality.

During the thirteenth and fourteenth centuries, the foundations of the Venetian empire, rather than being located in a vast extension of land, existed in the form of key islands and ports stretching all the way from Venice to most states in the Eastern Mediterranean. In all, the Venetian empire formed a chain of safe ports and harbors which allowed Venetian merchant galleys to sail undisturbed into the ports of Armenia, the Byzantine Empire, Egypt, etc.

Thus, places such as Modon, Coron, Negroponte and Crete, more than providing valuable resources to the Venetians, which in the case of Crete it did, were vital possessions from where the trade routes to the East, the arteries of Venice's economic life, could be effectively protected against any possible enemy or threat. Venetian policies for the Eastern Mediterranean outright demanded economic privileges in and monopoly of the trading depots of the East, conditions which could only sprang in a peaceful milieu, a pax Veneta.

By the late thirteenth century, however, the Venetian hegemony over the Eastern Mediterranean was challenged by a rising Crown of Aragón, which from the 1220 s had undertaken an expansionist policy in the Mediterranean world. The Catalan takeover of Athens all but overtly signaled to the Venetians a defiance to their control of the profitable eastern trade by the Arago-Catalan empire. From the Venetian perspective, the Catalan presence in and control over Athens were directly orchestrated by the Aragonese Crown, as it had previously schemed the takeover of Sicily and Sardinia; Venetian interests in the region deemed as urgent the total neutralization of the Catalans in Athens.

Within this context, an analysis of surviving Venetian and Catalan sources and documentation, for the first three decades of the fourteenth century,

${ }^{2}$ This colonial and expansionist pattern prevailed among Western Mediterranean societies until the center of European power shifted from the Mediterranean basin to the Atlantic. However, it survived in the imperial evolutions of Portugal and The Netherlands in the fifteenth, sixteenth and seventeenth centuries. Portugal, for example, occupied a chain of island groups, like the Cape Verde and Sãgo Tomé groups, and ports, like Luanda (founded in 1576), extending all the way to India and her trade. A final sample of this policy can be seen in US expansion in the Pacific. North American merchants could sail from California to China, after 1898. without stopping at any foreign port. In all these instances, such pattern of colonial expansionism allowed these societies to protect their trading routes, and to exert a direct control over foreign markets without having to spend their energies in governing or administering extensive areas. 
will reveal the distrust with which the Venetians observed the behavior of the Catalan Company in Athens. For the Venetians, the Catalan Company had too close ties with the mother ships, Sicily and Aragón. Likewise, Venetian exasperation swelled in respond to the lukewarm actions taken by the Aragonese and Sicilian crowns, whenever asked to control their bratty Catalan Company. This all but proved to the Serenissima the Aragonese and Sicilian plotting and manipulation of the events of 1311 that brought about Catalan domination over Athens.

For Venice, the conquest and takeover of the Duchy of Athens by the Catalan Company was the last step needed by the Crown of Aragón prior to crossing the threshold of complete commercial domination over the Mediterranean. More than a casual occurrence, the Catalan presence in Athens was a meticulously schemed plot aimed at checkmating Venetian monopoly of the Eastern Mediterranean trade.

\section{TERRITORIAL EXPANSION OF VENICE AND ARAGÓN IN THE THIRTEENTH CENTURY}

The thirteenth century is clearly a period of territorial and economic expansion for both the Venetian Republic and the Crown of Aragón. Venice and Aragón carved for themselves two insular and maritime empires in which the bottom line was the assurance and growth of their trade routes and markets. In the case of Venice, she already had mustered an economic empire stretching to the eastern coasts of the Mediterranean, and her territorial enlargement in the East was a consequence of her trading empire. On the other hand, Aragón had an imperial evolution in which her mercantile empire was a consequence and not a cause of her territorial augmentation. Though Aragonese and Catalan merchants were already numerous in the Western Mediterranean waters prior to the territorial growth of the Crown of Aragon, her conquest of several strategic islands and ports during the thirteenth century, enabled Aragón to create a trading empire that was carefully, if not worrisomely, watched by Genova, Pisa, and in the fourteenth century, by Venice.

Venetian land holdings in the East increased in the early thirteenth century as a result of the Fourth Crusade. According to the Chronique de Morée, several French barons joined forces in 1202 under the banners of a new crusade ${ }^{3}$. Among the preparations undertaken for this expedition, the barons requested the assistance of Venice in the form of galleys, which were to transport the crusaders to their destination, Egypt. However, and as a re-

${ }^{3}$ Among them, the Chronique de Moree mentions Geoffrey de Villehardouin and the counts of Champagne. Toulouse and Flandres. See Juan FERRANDEZ DE HEFEDIA, Chronique de Moreé. Osnabrück, 1968, pp. 1-2. 
sult of a series of problems, the French barons could not come up with the money to pay the Venetians. In the ensuing negotiations, the Venetians asked for the aid of these crusaders in recovering the city of Zara, in Dalmatia, wich [had] revolted [agains Venetian authority] ${ }^{4}$. From Zara, and due to a request from Alexis, the son of the Byzantine emperor Isaac II (1185-1195/ 1203-1204), and of a papal legate, the crusaders marched on Constantinople, returning in 1203 the imperial throne to Isaac and his son Alexis (the IV, 1203-1204). However, they were again overthrown in 1204 , but this time they were executed. The revolt led by the new emperor Alexis V Ducas (1204), prompted another intervention from the crusading armies, which stormed and occupied the city in 1204.

The primary result of the Fourth Crusade was the establishment of the Latin Empire of Constantinople. With the fall of the city, and with Pope Innocent III's blessings, the crusader armies took over the empire and divided it among themselves. As one of the victorious parties, Venice received threeeighth of the empire, territories that more than enhanced Venetian ability to expand and protect her trade with the East ${ }^{5}$. Instead of entirely occupying their newly acquired empire, the Venetians «understood that it was more prudent to limit themselves to a solid occupation of the naval stations ${ }^{6}$. Thus, Venice assume possession of only the Acayan cities of Modon and Coron (both in 1206), and of the islands of Crete (1204), and Negroponte (1209), entrusting the rest of her eastern domains to Venetian families and autonomous representatives. In return for these grants, they had to protect «the honor and interests of Venice in Romania and... her possessions and rights», as well as «ensuring to the Venetians the safety and freedom of trading... and exporting without playing any tariff ${ }^{7}$ ?

Venice expanded her commerce during the thirteenth century within this imperialist framework. On one hand, she possessed important and

\footnotetext{
4 «[... que, ho le pagasen toda la moneda que devian dar, o que ellos deviesen servir el comun de Venecia en recobrar Jadra [Zara] que era rebellada... \$. FerRdindeZ. Chronique, p. 8.

${ }_{5}^{5}$ \&Et dicho legado dixo al capitan \& á los otros que él era contento \& les daua licencia de part del papa que pudiessen tomar el dicho imperio de Contastinoble para ellos, reservado siempre que, conquistando el dicho imperio de Contastinoble, deuiessen dar al papa todo los derechos eclesiasticoss. FERRANDEZ, Chronique, p. 14. Regarding the partition of the Byzantine Empire, the Chronique says that Venice received only one-fourth of it. However, as contemporary documentation attests, the Venetian doge adopted the title of adominus quarta partis et dimidie totus imperii Romanien.

${ }^{6}$ George T. Denvis, Byzantium and the Franks, 1350-1420, London, 1982, p. 220. See especially chapter XVII, «Problemi storici concernenti i rapporti tra Venezia i suoi domini diretti e le signorie feodali nelle isole grechew.

7 all s'emploiera pour I'honneur et l'intérêt de Venise en Romanie et pour la conservation de ses possessions et de ses droits». R.J. LOENERTZ, Byzantina ef Franco-Graeca (henceforth BYZ), Rome, 1978, doc. 8, p. 145, all assurera aux Vénetiens la securité et la liberté de commereer dans ses territorires, sans payer auoun droits, LOENERTZ, BYZ, doc. 9, p. 145.
} 
strategic territories in the Eastern Mediterranean from where to safeguard her trade. At the same time, she had several metropolitan-born rulers and allies administering other Venetian areas, where Venetian merchants enjoyed economic and trading privileges. These satellite rulers also cooperated in checking any rising threat or power in the region ${ }^{8}$. Similarly, Venice also extended her sphere of influence over other areas of continental Romania. In 1262, Guillaum de Villehardouin, prince of Acaya, signed a treaty with the Serenissima, granting Venetian traders several concessions, while giving Venice control over the weights and measures in the region ${ }^{9}$.

Altogether, by the second half of the thirteenth century, Venice had achieved the undisputed mastery of the Levant's commerce. However, with the restoration of the Byzantine Empire in 1261, Venetian mercantile activities remained under constant attack from Constantinople, still at odd with the Serenissima for her role in the wars of 1204. Nonetheless, Venice smoothed relations with the Byzantines by the early fourteenth century. In 1302, Venice signed a trade agreement with the Byzantine emperor Andronicus II, a treaty that was followed up by several commercial concessions in 1303. Likewise, treaties were also signed at this time with Egypt, Syria, Tunis, and Persia ${ }^{10}$. In all, Venice was lord and master of the eastern trade, her merchant galleys reaching ports from Tunis to Egypt, from Armenia to Constantinople.

Somewhat parallel in magnitude was the economic and territorial expansion of the Crown of Aragón in the thirteenth century. In the 1220s, the Aragonese and Catalans had resumed their eholy reconquest» of the Iberian peninsula, launching an amphibian invasion on Mallorca. During the following decade, they invaded and absorbed Muslim Valencia; by the $1270 \mathrm{~s}$, their presence was also felt in North Africa, where they soon obtained the island of Djerba, as well as economic concessions in the cities of Tunis and Bona ${ }^{11}$. However, no prize was as coveted by the Aragonese Crown as the Kingdom of Sicily. Since 1279, King Pedro III of Aragón was organizing an invasion of this island, which his wife Constance claimed as inheritance from her father, Manfred of Sicily, killed by Charles d'Anjou at the Battle

${ }^{8}$ alls feron vive guerre au prince d'Achaie et ne concluront pas de paix séparée». LOENERTZ, BYZ, docs, 48 and 49, p. 157.

${ }^{9}$ aPoids et mesures dependent de Venisen. LoenerTz, BYZ, doc. 67, p. 161

${ }^{10}$ For the respective commercial treaties with Egypt, Syria, Tunis, Persia, and Byzantium, see George M. THOMAS, Diplomatarium Veneto-Levanrimum (henceforth DVL), New York, 1880 , docs. 4.5 and 6 , pp. $5-12 ;$ doc. 17 , p. $30 ;$ doc. 20 , p. $33 ;$ doc. 26, p. $47 ;$ and does. 7 and 8 , pp. $12-19$.

11 For the conquest of Muslim Valencia, see Robert 1. BURNs, S.J., Muslims Christians, and Jews in the crusader kingdom of Valencia, Cambridge, 1984. For the expansion of the Crown of Aragón, see Lluís Nicot.Au D'OLwER, L'Expansió de Catalunya en la Mediterrània oriental, Barcelona, 1926, and J.L. SHNEIDMAN, The Rise of the Aragonese-Catalan Empire, 1200-1350, 2 vols, New York, 1970. 
of Benevento in $1266^{12}$. The Sicilian Vespers (1282), and the ensuing Sicilian Wars (1283-1302), resulted in the Arago-Catalan seizure of Sicily and the enhancement of Aragón's mercantile influence in the region with the acquisition of Malta, Pantelleria, and Calabria, areas of strategic value in the central Mediterranean waters. The Arago-Catalan expansion was augmented by Pope Boniface VIII's grant of Sardinia and Corsica as fiefs to Aragón in 1297. By the early fourteenth century, with the only exception of Corsica, Aragón possessed or was in the process of dominating every major island in the Western Mediterranean, while simultaneously controlling the Mediterranean coast from Provence to Alicante.

As with Venice, the territorial growth of the Crown of Aragón meant increasing trade. By the turn of the century. Aragón was expanding her economic activities into the Eastern Mediterranean, Catalan and Aragonese galleys reaching the ports of Egypt, Armenia and Cyprus, while her merchants traded in Damascus, Persia and Central Asia ${ }^{13}$.

Thus, by the early fourteenth century, Venice and Aragón had become the two dominant powers in the Mediterranean trade. Up to then, Venice and Aragón had remained at ease with one another, partly due to the confinement of both powers to separate spheres in the Mediterranean: Venice to the East, Aragón to the West ${ }^{14}$. Nevertheless, a series of events in the early fourteenth century brought this coexistence to an almost certain end. At the center of these events was the Arago-Catalan expansion in Romania.

As early as 1304, King Federico III of Sicily expressed his hopes of conquering Acaya in a letter written to his brother Jaume II of Aragón ${ }^{15}$. Though Federico's attempts failed, the threat posed by the Catalans continued with the arrival and rooting of the mercenary Catalan Company. By 1311, the Catalan had defeated the armies of Gualtier de Brienne, duke of Athens, at the Battle of Cephisus. With de Brienne's defeat and death, the Duchy of Athens was left at the mercy of the Catalans. With this, the mercantile machineries of Venice and Aragón collided, for now the Catalan and Aragonese merchants had not only «broken the Italian monopoly in the Western Mediterranean... [but] were free to challenge the Venetians in the Greek waters ${ }^{16}$. What followed were years of cautious acts and strained relations between the Catalans of Athens and the Venetians. For the next two decades, even though Venice and Aragón did

${ }^{12}$ See Helene WURNszowskI, «Conjuraciones y alianzas políticas del rey Pedro de Aragon contra Carlos de Anjou antes de las Vísperas Sicilianas", Boletin de la Real Academia de Historia, CVII (1935), 547-602.

${ }^{13}$ ShIneIDMan, The Rise, vol. 2, pp. 335-336.

14 Ramon Muntaner, Crónica, Madrid, 1970, ch. 116, p. 251.

15 eltem fa saber lo dit senyor rey Frederic al dit senyor rey d'Arago que ell [enten] sobra lo feit de Romania, ço n'a trames al senyor papa e enten lo dit [senyor rey] Frederic aver sobra daquest feit aiuda e consell del dit senyor rey d'Aragon quan menester li seraw. Antoni Rubió i Lluch, Diplomatari de I'Orient Catala (henceforth DOC), Barcelona, 1947, doc. XI, p. 12.

${ }^{16}$ SHNEIDMAN. The Rise, p. 347. 
not clash militarily, the Catalans and the Venetians in Romania found themselves in a struggle that would determine Venetian mercantile hegemony in the region.

\section{CATALAN PRESENCE IN ROMANIA AND VENETIAN RESPONSE, 1302-1331}

The Catalan Company arrived at the Byzantine shores in 1302, as a mercenary force recruited by emperor Andronicus II, and entrusted with the defense of the imperial holdings in Asia Minor, imperiled by the ever increasing menace of the Turks. As recorded in Ramon Muntaner's Crónica, Roger de Flor, with the approval of Federico III of Sicily, sent an embassy offering his and his army's services to Andronicus, «for the Turks have deprived him of a thirty days journey of his land ${ }^{17}$. Soon after their arrival, however, the Catalans fought and massacred the Genoese merchants in Constantinople, a massacre that proved beneficial and advantageous to the Venetians, who subsequently filled the vacuum created by the annihilated Genoese $^{18}$.

However, the business arraignment struck between Andronicus and the Company did not last long. Muntaner blamed Andronicus's son, Michael IX Paleologus, for the hostilities that ensued between the Byzantine emperor and the Catalans. Muntaner pointed to Michael's jealousy towards Roger de Flor, by now megaduke of the empire ${ }^{19}$. Likewise, Muntaner accused Andronicus of attempting to embezzle the Catalans by paying their services with devalued coins, an action that khe did maliciously...[for] he would rather have preferred to see every Frank [Catalan] either dead or out of his empire ${ }^{20}$. Regardless of the absolution given by Muntaner to the Company, the fact remains that the Catalans had emerged as a powerful force within the empire; on one hand, they defeated the Turks in Anatolia and the rebel lord of Lampsaki, thus commanding considerable military strength. while on the other, Roger de Flor, head of the Company, had achieved a powerful and influential position within the Byzantine ruling hierarchy. Andronicus II logically reacted to this unfolding power by attempting to root it out; massacres of Catalans followed in Constantinople, Adrianople and

${ }^{17}$ Muntaner, Crónica, ch. 199, p. 411.

${ }_{18}$ Muntaner, Crónica, ch. 202, p. 416. The massacres of Genoese merchants in Constantinople coincided, not surprisingly, with the signing of a Veneto-Byzantine economic and commercial agreement (see n.10).

19 Muntaner, Crónica, ch. 203, p. 420.

20 «Y esto lo hacía él para mal, y para que entrase odio y mala voluntad entre el pueblo y la hueste, pues en cuanto él hubo logrado lo que se proponía, en todas sus guerras, quisiera que los francos estuvieran todos muertos o fuera del imperios. MunTanir, Crónica, ch. 210, p. 432. 
Gallipoli. This last site remained as a focus of Catalan resistance for close to three years (ca. 1305-1307). By then, the Catalans had moved into Romania, where they survived by pillaging and ransacking the local population $^{21}$.

At the same time the Catalan Company left the vicinities of Constantinople, Federico III of Sicily, still nominal lord of this mercenary force, appointed his nephew, Ferran of Mallorca, as his representative to the Company ${ }^{22}$. Nonetheleess, Bernardo de Rocafort, the new leader of the Company, refused to acknowledge Federico as their lord; instead, Rocafort nominated Ferran himself to this position. Ferran opposed this move of Rocafort, but remained with the Catalans until their total evacuation of Gallipoli and relocation in Salonica. Once there, Ferran departed on his journey back to Sicily, a journey cut short by his arrest at Venetian Negroponte. The Venetians then turned him over to the French officials at the Duchy of Athens ${ }^{23}$. During Ferran's captivity in Athens, the Catalan Company, under orders from JaumeI II of Aragón, swore allegiance to Charles of Valois, Jaume's brother-in-law24. With the French assuming control over the Company, Ferran was liberated. Simultaneously, Bernardo de Rocafort was turned over to Robert of Naples (1309-1343), by Charles of Valois' agent in Romania, Thibault de Cepoy. Rocafort met his death in Naples; the Catalan Company. though under the guardianship of de Cepoy, remained leaderless in

${ }^{21}$ For an in-depth analysis on the role of the Catalan Company within the eastern political arena, see Robert 1. BuRvS, S.J., *Catalan Company and the European Powers, 1305-1311\%, Speculum, XXIX (1954), 751-771.

22 eltem, promisit dictus dominus noster rex ac consensit et voluit, quod dictus dominus Ferandus recipiatur et habeatur a predicta gente dicti domini regis que est in dictis partibus Romanie ut persona dicti domini nostri regis et tamquam vicem et locum tenens in dictis partibus eiusdem domini nostri regis, et quod predicta gens dicti domini nostri regis, que est in dictis partibus, eidem domini infanto Ferando, nomine et pro parte ejusdem domini regis, faciat fidem et homanagiums. RuBro r LuUCH, DOC, doc, xxxt1. p. 39.

${ }^{23}$ Muntaner, Crónica, ch. 235, p. 484. Burns has indicated that at this point Venice, though securing more amicable and profitable relations with the Byzantines, still saw othe great Valois crusade-plans against Byzantium... as the long-range but permanent solution to her Levantine woesw. Thus, Venice's complicity in Ferran's incarceration resulted from her desires to set a political milieu that would ensure her economic domination. See BURNS, *Catalan Companyn, p. 754.

24 жqua propter nos omnes et singulos vestrum affectuose rogamus ac fidelitati vestre qua nobis naturaliter estis astricti precipimus et mandamus, quatenus sicuti graciam nostram caram geritis, ac nobis desideratis placere nostreque satisfacere voluntati, sic in negociis imperii supradictis placere pro dicto comite [Charles de Valois] agitis fideliter, sollicite, fervide, preseverantes in eis, sicque strenue ac viriliter insistatis, vestra laudabilia principia fine laudabili concludendo, ut inde vestra probata strenuitas, laudis apud omnes extollatur preconio, coram nobisque efficiamini propterea obedientes et grati. insuper et dicti consaguinei nostri qui labores vestros et merita largiflue et liberaliter compensabit omnes vestrum et quilibet digne retribucionis premium consequaturs. Ruaro I LUCH, DOC, doc. xxxix, p. 49 
Romania. Thibaut de Cepoy was unable to assert his control over the Company, relinquishing it in 1310 . Joseph Petit indicates, in a manner which seems to eternalize the Frankish apathy towards the Catalan Company, that «what little Muntaner revealed to us regarding the Catalan Company shows the impossibility of leading.... this undisciplined people ${ }^{25}$.

An unexpected development in Levantine politics, however, brought new hopes to the Catalan Company, which continued its wandering and sacking of the Greek countryside. Earlier, in 1308, Guido de la Roche, duke of Athens, had died heirless. In 1309, the new duke and candidate of Robert of Naples, Gualtier de Brienne, arrived to his domains and found the cities of Neopatras and Epirus in open revolt against his rule, outright declaring their independence from the duchy. While Setton indicates that de Brienne turned to the Catalans due to his urgent need for an army ${ }^{26}$, de Brienne might have been following orders from his Angevine bosses, whom, as Robert I. Burns has demonstrated ${ }^{27}$ sought the utilization of the Catalans for their primary goal, the reestablishment of a Latin empire in the East. Though Gualtier de Brienne recovered Neopatras and Epirus with the assistance of the Catalans, conflicts soon ensued, in what Muntaner labelled as the attempt of de Brienne to dispose of the Catalans, namely by paying their services «with a noose ${ }^{28}$. The result of this clash, as already mentioned, was the Battle of Cephisus, in which Gualtier lost not only his duchy, but also his duchy.

The menacing presence of the Catalans in Athens was already a matter concerning the Venetians since 1308 . In a letter to the baiulus of Negroponte, Belletto Faletro, the Venetian doge, Pietro Gradenigo (1289-1311), expressed his concern over the announced marriage between Bernardo de Rocafort and the sister of Guido de la Roche, duke of Athens. Gradenigo feared the Catalans' intentions, «specially of their coming and taking over the island of Negropontes ${ }^{29}$. Fortunately for the Venetians, Thibault de Cepoy handed Rocafort over to Robert of Naples, who had him executed.

However, Venice's preoccupation did not die with Rocafort. In 1309, Faletro notified Gradenigo of an anti-Venetian alliance between the Catalans under Cepoy and some Greeks. Gradenigo ordered the baiulus of Negroponte to defend the island, etaking care of our honor and the safety of Negroponte ${ }^{30}$

${ }^{25}$ See Muntaner, Crónica, ch. 239. pp, 491-493.

${ }^{26}$ See Serton, Catalan Domination, p f 3

${ }^{27}$ Burns, $\propto$ Catalan Companyw, p. 763.

${ }^{28}$ MUNTANER, Crónica, ch. 240, p. 494.

29 *...matrimonium esse conventum inter sororem duci Athenarum et Bernardum, dictum Rocchaforte, magnum marescalum totius societatis.... et de intentione ipsorum, specialiter de veniendo ad accipiendum insulam Nigropontisn. R.J. LOENERTz. Les Ghisi: Dynastes Vénetiens dans I'Archipel, 1207-1390 (henceforth LG), Florence, 1975, doc. 19, p. 201. 
The convergence of a series of events encapsulated the rationale behind the Serenissima's defensive schizophrenia, which equated the Catalan Company with the Crown of Aragón. The Company was always preceded by the banners and royal pennants of the House of Aragon, whose Sicilian members held the title of dukes of Athens and Neopatras. Also, the attempts by the Papacy and the Angevines to integrate the Catalan Company into their broader crusading schemes for the East, which were to an extent beneficial to Venice, had completely failed due to the Catalans' independent-minded behavior and Jaume of Aragón's lighthearted support to these efforts ${ }^{31}$. Thus, and although the Company was a highly independent political entity, for the Venetians and other powers in the region, the Company was directly connected to and controlled by the Crown of Aragón, which strived to break the Venetian trade monopoly in the East. Venice perceived the Catalan takeover of Athens as providing this mercantile power with the stepping stone needed to dominate eastern trade, using for this purpose the always menacing Turks from Asia Minor.

Consequently, the first years of Catalan rule in Athens were marked by a hysterical diplomacy on the part of most power in Romania, a diplomacy that aimed at effecting the withdrawal of the Company from the duchy. If anytning can be said regarding the Venetians at this time is that their diplomacy was characterized by the shrewdness and pragmatism that would entail them to remain as an active power in the region long after the of Constantinople to the Turks in 1453.

For four years, from 1311 to 1314, Pope Clement V plotted to rid Romania, and his French allies, of the Catalan invaders, first by using them in another crusade to the Holy Land ${ }^{32}$, and later by demanding their evacuation of Athens, under the threat of excommunication ${ }^{33}$. Neither martyrdom nor God's wrath got them out of Athens. Meanwhile, Venice devoted herself at securing her role in the East. In 1315 , Federico III of Sicily announ-

30 a...procurando que nostrum honorem respiciant et salvationem terre Nigropontis..... LoENERTZ, LG, doc. 23 , p. 204.

${ }^{31}$ Burns indicated that $\propto$ As Rubió $i$ Lluch astutely notes, [Jaume] never for an instant lost sight of his jurisdiction over the Company. He could and did disavow this connection when policy so counselleds. BURNs, Catalan Company?, p. 767.

32 eapres senyor jo en P. de Queralt ab en G. Olomar ensems parle ab la vicecanciller del papa d'aquests fets largament, recomtali tot ço que haviem dit al senyor papa, ne que aytant com ell nos navia respost, e ell dix nos que aytant com ell conexia be, tenia per impossible e por sobre difficil, passatge qui s faes en la terra sancta per mar, mas be vehia que si Granada n'era levada, que leu seria nom en la Barberia e puys per terra ferma sen poria hom anar de la e que aquesta era la conquesta rahonabla e possiblas, RUBIO I LLUCH, DOC, doc. II, p. 66.

33 aet tam celsitudinis tue quam universorum fidelium quos fidei zelus angit, intersit huiusmodi pestilenti sevitie reproborum solicitis studiis celeribus et oportunis remediis obviare, serenitatem regiam rogamus et obsecramus in domino tibi in remissionen peccaminum iniugentes, quatinus pie considerans quam sit meritorium apud Deum partes illas cultas fidelibus ac tot solemmes ecclesias et alia innumera pia loca ecclesiasticasque personas partium earumdem 
ced to Venice that he had extracted a promise from his nephew, Ferran of Mallorca, that he would wnot offend your Communes, during his forthcoming attack against French Acaya ${ }^{34}$. In theory, this reassurance would have pleased the Serenissima, but the thought of a Catalan Acaya could only have cast the fear of an uncontrollable bleeding to the hemophiliac Venetian monopoly over the eastern trade. Acaya was not simply another plot of land in Romania. Rather, its control by a hostile mercantile and maritime empire such as Aragón could endanger Venetian interests at and control of Modon and Coron; Athens emasculating the Venetians at Negroponte. If fate ever showed her love for the Serenissima, it was when Ferran died late in 1316, after almost succeeding in his undertaking.

While Modon and Coron survived Catalan encroachment, Negroponte proved to be the Venetian Achilles' heel vis-à-vis the Catalans. Though the nominal ruler of Negroponte, Venice had relied on vassals for the administration of the island. However, this system often proved to be problematic, primarily due to the continuous bickering and rivalry among these representatives of the Commune. A year after the death of Ferran, Mathilde de Hainaut, princess of Acaya (1313-1318), asked Doge Giovanni Soranzo (1312-1328), to mediate a dispute between Boniface of Verona, lord of Carystos and of a third of Negroponte, and Andrea Cornaro, lord of Carpathos and a sixth of the said island. According to Mathilde, Cornaro had allowed 2.000 Catalans from Athens to enter the city of Negroponte, thus threatening the entire island with a Catalan take over. The Venetians responded by sending a new baiulus to Negroponte, Francesco Dandolo (1317-1319), with an army ready to defend the island against the Catalans ${ }^{35}$.

But no sooner had Dandolo been appointed when news arrived of the impending marriage of Alfonso Fadrique, successor to his brother Manfred to the ducal throne of Athens, with Maria of Verona, daughter of the lord of Carystos. This marriage, for all practical purposes, gave Alfonso

abhuiusmodi peste et exterminio liberare universis de regno et terris tuis in dicta societate morantibus sub certis temporalibus penis, prout celsitudo tua expedire cognoverit, des per tuas litteras in mandatis, ipos aliis salubribus monitionibus et hortationibus inducendo, ut partes illas castra, terras et villas ac loca quecumque que in dictis partibus fidelibus abstulenunt et occuparunt et detinent occupata, ecclesiis et nobilibus aliisque fidelibus illarum partium quorum esse noscuntur, libera et expedita dimictant nec deinceps in preiudicium partium illarum societati adhereant supradicte, sed partes ipsas omnino dimictant, ad illas in prejudicium fidelium eas habitantium nullatenus reversuri», RUBIO I LLUCH, DOC, doc, LXVI, p. 83.

34 equam etiam mutuae obligationes quae inter nos et eum hactenus obvenerunt, dudum antea requisitionem per dictum vestrum nuntium nobis factam, vestris semper indemnitatibus providendo, ac homagium ad forum Aragoniac, Usagium Barchinonensem manibus et ore ac corporale ad sancta Dei Evangelia juramentum de non offendendo Comune vestrum, vas, et subditos vestros*. RuBio i LLUCH, DOC, doe, Lxxv, pp, 92-93.

35 LOENERTZ, BYZ, doc. 5, p. 187. 
and the Catalans a solid foothold in the island of Negroponte. As a result of this and similar instances of Catalan expansion, Catalan-Venetian relations, or confrontation, in Romania reached a tense and hectic peak in the years 1317,1318 , and 1319 . The Catalans were seemingly putting all their efforts in destroying Venetian control over the Aegean islands. In 17 and 18 March 1318, Jean de Gravina, prince of Acaya (1318-1333), Robert of Naples and Philip of Tarento wrote to Doge Giovanni Soranzo notifying him on the attack launched by the Catalans on Negroponte ${ }^{36}$. Likewise, on 21 June 1318, and on 16 July 1318, the duke of Crete, Niccola Zane, reported to Soranzo an attack by a combined Turco-Catalan force at Sitia, on the northeast coast of the island ${ }^{37}$. On 26 June 1318, Francesco Dandolo wrote Soranzo informing him of a Catalan galley that had travelled to Anatolia and returned with 1.000 to 5.000 Turks to an undisclosed destination, most likely Athens ${ }^{38}$. Again, on 16 July 1318 , Zane wrote another letter to Soranzo indicating that there existed an alliance among the Turks, Catalans and Sicilians preparing an invasion on Negroponte ${ }^{39}$.

Thus, for the Venetians, the Catalan takeover of Athens was the first phase of an Aragonese (and Turkish), scheme to expel the Serenissima from the area, and to assume their trade monopoly. While the hostilities ensued in Romania, Venice sent a diplomatic mission to Federico of Sicily, father of Alfonso Fadrique, hoping to put an end to the attacks by the Company on its galleys and citizens ${ }^{40}$. In the mean time, Alfonso Fadrique wrote a letter to Francesco Dandolo, stressing that the Catalans «indeed intend [ed] to observe the [existing] truce for [the saxe] of peace and tranquility" with the Venetians ${ }^{41}$. Nevertheless, the first response on the part of the Sicilian monarch to Venetian accusations, was to categorically refute them. On an attack by Alfonso's men against a Venetian galley from Crete, that had occurred in the gulf of Negroponte, Federico pointed out that the aforementioned galley was in reality from Thessalonica, and its crewmen were from that city, ruled by the Byzantine emperor, «who is the enemy of the Roman Church and of every faithful Christian». Thus,

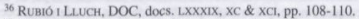

37 Thомаs, DVL, docs. 61 \& 62, pp. 107-109.

38 equi vadunt pro accipiendo Turcos in bona quantitate a mille usque mille et quingentos\%. LA Ameno-Veneto. Venice 1893, doc. 280, p. 142; RUBIO I LLUCH, DOC, doc. XCVm. p. 119.

39 Thomas, DVL, doc. 63, pp. 109-110.

40 "nos deliberaveramus et feceramus quendam nostrum solempnem ambaxatorem mittendum, et jam misimus ad dominus regem Fredericum ipsius Alfonsi genitorem, et speramus quod per ipsam nostram ambaxatam ipse dictus rex taliter ordinabit et faciet cum effectu, quod facta Negropontiss, RuBio i LLUCH. DOC. doc. xCII, p. 111.

41 «nos enim treguam amore pacis et tranquilitatem vobis et vestris intendemus inviolabiliter observare», RuBIO I LLUCH, DOC, doc, XCV, p. 115. 
it was «proper for those men of the aforesaid Company to capture the aforementioned hostile galley, the men and the things in its ${ }^{42}$.

Similarly, as for Alfonso's attempts to invade the island of Melos. Federico dismissed the charges of wrongdoing on the grounds that the lord of this island, Guglielmo Sanudo (1303-1323), though Venetian, was a vassal of the princess of Acaya, Mathilde de Hainaut, also an enemy of the Catalans. Therefore, «it [was] proper for the said lord Alfonso to invade the said island, and in this the said Commune had not been harmed, for...the said island belongs to the princess of Acaya..., and the said Commune has no right in the aforementioned islands ${ }^{43}$.

In the end, Federico demanded from the Venetians the restoration of several castles, towns and lands in the island of Negroponte to their righteous owner, Maria of Verona, wife of Alfonso Fadrique ${ }^{44}$. Though Federico seemed to have turned the table on Venice, he immediately dispatched an embassy to Venice, entrusted with "settling with the aforesaid Commune, sindicates, procurators or legates of the same Commune, the damages inflicted by both sides", and with «reaching a final peace and agreement, or a long lasting truce between the said Commune of Venice, her citizens and subjects, and Alfonso and the entire aforesaid army [the Catalan Company]». However, in doing so, the Sicilian embassy had to ensure that «Alfonso and Maria, his wife, [would] be allow to take possession of [their] towns and lands in the island of Negroponte», and that Venice would not «force the said Alfonso into paying homage [to them] $\aleph^{45}$. Federico's attitude and policy, thus, demanded a peace or nonaggression pact with Venice, without limiting Catalan territorial - and economic - expansion in the East. Venetian possessions would not be directly targeted, but all other areas were considered up for grab, and Federico hoped they would consequently Catalans.

42 squod predicta barca et homines existentes in ea fuerunt de regno Sallonichi ac oriundi de regno predicto, quod regnum est sub dominio imperatoris Constantinopolitani, qui imperator est hostis Romane ecclesie ac omnium fidelium christianorum, et sic licut illis de societate predicta capere hostiliter barcam predictarn, homines et res existentes in eas. RUBIo I LuCH. DOC, doc. CIII, p. 124; THOMAs, DVI, doc. 64, p. 110.

43 set propterea, dictus dominus Alphonsus licite potuit invadere dictam insulam, et in hoc non leditur dictam commune, quia principaliter et directe et de dicta insula est principisse Achaye et sub dominio ipsius et dictum commune nullum jus habet in insula supradictas. RUBIó I LeUCH, DOC, doc. CII, pp. 124-125; Thomas, DVL, doc, 64, p. 111.

${ }_{44}$ Rubí i Luech. DOC. doc, CII, p. 126; Thomas, DVL, doc, 64. D. p. 112.

45 ret ad componendum cum communi predicto, sindicis, procuratoribus seu nuntijs communis ipsius de dampnis utrinque illatis...

set ad ineundum etiam finalem pacem et concordiam vel longam treguam inter dictum commune Venetiarum, cives et subditos eius ac eosdem Alphonsum et universitatern predicti exercitus...

$\rightarrow$ que competunt dicto Alphonso et Marule, uxori eius, in castris et terris possitis in insula Nigropontis, nec non obligandum dictum Alphonsum ad presentationem servitij...n. RUBió LUCH, DOC, doc. cIV, p. 127-128; ThOMAs, DVL, doc. 65, p. 114. 
A truce was worked out by the end of 1318. On it, Alfonso and Maria received their holdings in Negroponte, but only after agreeing to withdraw from Romania all their «galleys or ships..., with the exception of one galley or ship for [the sole purpose of] sending news or envoys ${ }^{46}$. By 1319 , a peace treaty was signed by Venice, Sicily and the Catalan Company. After the customary introduction of the parties involved in the treaty, the first condition imposed by the Venetians aimed at protecting their interests in the region, namely the trade routes and sealanes. The Catalans in Athens were forbidden from having any armed galley in the duchy, nor in the waters of Negroponte, except from those already there, which nevertheless had to be stripped of all weapons. Likewise, the Catalans in Athens had to end and discourage all piratical activities in their territories, while paying reparations to Venice and its citizens for whatever damage the Catalans might have inflicted upon the Commune ${ }^{47}$.

With the treaty of 1319 , Venice coped with the first major crisis in her relation with the Company. For the time being, the Venetians had established and underlined the fact that they were the masters of the Eastern Mediterranean and of its trade. The Serenissima was not about to tolerate the expansionist policies of any maritime or mercantile power in Romania. However, the Catalans in Athens soon found ways to circumvent the treaty of 1319. While the agreement was renewed in 1321 , far from settling down all the disputes between the Catalans and the Venetians, the events which followed 1321 brought with hem a new wave of awes for the Venetians and the resumption of hostilities ${ }^{48}$.

Several tangible factors remained trully unsolved and tainting VenetianCatalan relations in the region. At issue were the control of Carystos, the dubious economic activities of the Catalans, and the political and military behavior of the Company. At stake were Catalan presence in Romania, and Venetian monopoly of the eastern markets.

After 1319, the issue of Carystos was at least nominally resolved. While the right of Alfonso and Maria to the city was recognized by Venice, Maria's brother, Tomassino, took possession of this strategic port with the approval of the French princes and barons of Acaya, and of Venice. However, Tomassino died in 1325; Alfonso and Maria revived their claims to the city. On March 1326, Pietro dalle Carceri, Beatrice de Noyers (of the Verona family), and Bartolomeo Ghisi informed Doge Giovanni Soranzo of Maria's presence in the island, and her demands to receive the city of Carystos. They had refused granting her control over the city, for they considered

\footnotetext{
46 «quod predicta Compagna non habeat nec teneat nee teneri faciat in Romania in aliqua parte galleas vel ligna de cursu sea a remis, salvo quod habere possint unam galleam vel lignum tantum pro nuntijs et novis mittendiss. RuBió 1 LLUCH, DOC, doc, CVI, p. 129; THOMAs, DVL, doc. 66 , p. 115.

47 RuBIO I LLuch, DOC. CIX, pp. 132-134; Thomas, DVL, doc. 70, pp. 120-121.

${ }^{48}$ See SetTon, Catalan Domination, p. 27.
} 
this as posing a threat to Venice's interests, and thus asked Soranzo for his advised on this matter ${ }^{49}$. The city was occupied by the Catalans that same year, and continued as a source of malaise between the Company and the Serenissima until 1365, when Venice bought and occupied the city.

A similar problem revolved around Catalan trade activities in the region. The control of Athens by the Company provided Catalan, Valencian, Mallorcan, and Sicilian merchants with a lee in the Eastern Mediterranean from where their trade with Constantinople, Cyprus, Armenia, etc., flouri$\operatorname{shed}^{50}$. Among the most profitable commodities obtained in the East were slaves; however, the methods employed for their acquisition, namely piracy and kidnapping, brought the condemnation of the Catalans by the Avignonese Papacy and the indignation of other powers in Romania ${ }^{51}$. Both piracy and slavery, however, were common commercial activities practiced by every mercantile society; whether Christian or Muslim, in the medieval Mediterranean basin. Therefore, neither the condemnation by the Papacy nor the military retaliations conducted by others against the Catalans, had as its foundation moral outrage or a notion of Christian duty to eradicate this evil. In the case of the Avignonese Papacy and the French nobles of Acaya, their disgust toward Catalan activities ultimately reflected their desire to expel the Catalans from Athens. Likewise, they hoped that in doing so, they could, restore the ducal dynasty of the de Brienne, relatives of the Châtillon family, whose member, Gaucher de Porcieu had been constable of France, while his daughter, Jeanne de Châtillon, was the widow of Gualtier de Brienne, the Athenian duke killed in the Battle of Cephisus in $1311^{52}$.

For the Venetians, these activities of the Catalans underlined their unruliness, as well as the threat that they posed to the stability of the Eastern Mediterranean. The Catalans, both from Athens and other territories under the House of Aragón, and their Turkish and Greek associates had repeatedly seized Venetian possessions, and ransacked their merchant galleys in Greek waters $^{53}$. Piracy and Turco-Catalan attacks on Venetian citizens had been a matter addressed by the Venetians in their negotiations with the Sicilian

${ }^{49}$ LOENERTZ, BYZ, doc, 11, p. 189; RuBIO I LLUCH, DOC, docs. CXXX, CXXXI, cXXXII \& CXX-XIII, pp. 161-164.

5o Jesús La LINDE Abadia, La Corona de Aragón en el Mediterráneo Medieval 1229.7479, Zaragoza, 1973,pp. 218-219.

${ }_{51}$ On the slave trade, see LaLinde ABadia, La Corona, p. 322.

${ }_{52}$ Pope Clement $\mathrm{V}$ excommunicated the Catalan Company in 1314 (see RUBio I LLuch, DOC, docs. LXIY \& LXVI, pp. 80-81, 82-83). Pope John XXII renewed this excommunication in 1323 (see RUBIO 1 LLUCH. DOC, doc. CXX, pp. 148-149), and the ban of excommunication was in effect until 1363. In 14 June 1330. Pope John XXII preached a crusade against the Catalans (see RuBió I LuUCH, DOC, doc. C.pp. 189-191), a crusade that took place in 1331 and 1332, and that resulted in the defeat of the crusading armies of Gualtier li de Brienne.

53 See, for example, Rubió I LLUCh, DOC, doc. Cxxv1, pp. 157-158; Thomas, DVL, doc. 63, p. 110 . 
crown in 1318 and 1319. As already stated above, the treaties of 1319 and 1321 forced the Catalans to disarm all their galleys in the Duchy and in the surrounding waters, and to discourage all filibustering in the area. However, while the Catalans in Athens refrained themselves from engaging in these activities, as might be deduced from the lack of documentation to this effect after 1321, a conversely augmentation of these ventures by Catalan subjects from other areas, namely Catalunya and Mallorca, offered neither consolation nor guarantees to Venetian interests and merchants. The boldness of $\mathrm{Ca}$ talan piracy quickly rendered whatever promise they had made worthless. From the Venetian perspective, the worst part was the support Catalan buccaneers received from the Crown of Aragón. On 27 January 1329, Jaume III of Mallorca (1324-1349), petitioned the intervention of Doge Francesco Dandolo (1329-1331), on behalf of some Mallorcan and Catalan merchants who had been attacked, and their goods stolen by the Venetians in the island of Cerigo in 1326. The said merchants were en route from Thebes to Cyprus, when bad weather forced to seek refuge at Cerigo. Once there, their galley was assailed by the local Venetian subjects, resulting in the death of several crew members ${ }^{54}$. Dandolo ordered Cretan duke Giovanni Morosini to conduct an investigation regarding these allegations ${ }^{55}$. However, this inquiry revealed that the said merchants had engaged in filibustering and had attempted to kidnap «men from the island in order to extract them [from Cerigo] and sell them [as slaves] ${ }^{56}$. Nonetheless, on 27 August 1329, the Crown of Mallorca again requested the intervention of Dandolo on behalf of the same merchants ${ }^{57}$.

Facilitated by the possession of Athens, piracy by subjects of Aragon, Mallorca and Sicily, escalated in the East. This, in conjunction with an aggressive political and military behavior on the part of the Company during this decade, resulted as before in strained relations and on a fragile peace between the Venetian Commune and Catalan Athens. Though Federico of Sicily might have desired a temporal respite on hostilities with Venice, so as to concentrate all his energies against his traditional Angevine foes, the Company, while responding to Federico's expansionist wishes, followed their own plans of hostile behavior. Venice, on the other hand, had assumed the role of the Eastern Mediterranean police ${ }^{58}$. As a result of this, whenever the Catalans attacked Venetian territories or any other state in Romania, Venice had to respond in order to avoid the erosion of her power in the East.

${ }^{54}$ RLBio I LLUCH, DOC, doc, CXLII, pp. 173-175.

${ }^{55}$ RLB1O I LUUCH, DOC, doc, CXLY, pp. 176-177.

${ }^{36}$ aqui Catellani descenderunt in terram et ibant per insulam capiendo homines de insula pro portando extra ad vendenum et etiam capiebant animalia...p. RuBIo I LLECH, DOC, doc. CxLvH, p. 183.

${ }^{57}$ RuBió i LLUCH, DOC, doc, CXLVII, p. 183.

58 See Freddy Thiriet, La Romanie Vénétienne au Moyen Ảge, Paris, 1959, p. 163. 
Already by the turn of the century, Venice had reevaluated her eastern policy so as to accommodate the interests of France and Byzantium. However, this required bringing two hard core enemies to a peaceful coexistence. First, Venice had to deal with Angevine desires to restore the de Briennes to Athens and the sLatin" empire in Constantinople. Secondly, the Serenissima continued to discourage the Byzantine pursue to recreate its former imperial glories, primarily by booting the Angevines from Romania. If this was not enough to handle, Venice had also to figure out what to do with the disruptive behavior of the Catalans and Turks. In all, Venice strove to unite all Christian powers in the region against the detrimental presence of the Turks. This unification of powers would have created a virtual immunization of Venetian commercial concerns, as Venice assumed the leadership of this European alliance. Only the threat posed by the Catalans, via their association with the Anatolian Turks and anti-Western Greek rebels, had to be checked ${ }^{59}$.

As in 1319, when the forces of Alfonso Fadrique conquered the city of Neopatras and then annexed it to the Athenian duchy, the Catalans followed an expansionist blueprint which had among its goals the debacle of French Acaya. The House of Aragón had previously tried unsuccessfully to subjugate Acaya in 1315. But, by 1321, the odds of a Catalan takeover ominously went against the French, who also had to face the claims of a Byzantine emperor endeavoring to rebuild past honors.

On June 1321, Pietro Gradenigo, Provincial of the Friar Minor in Romania and representative of the French barons of Acaya to the Venetians, requested the intercession of Venice on behalf of French interests against the attacks of the Byzantines on the principality. Gradenigo had granted ipso facto control and suzerainty over Acaya to the Venetian Republic, since the Serenissima had truces with both the Byzantine emperor and the Catalans. Though the Catalan Company had been the only other alternative at the disposal of the French barons, they still considered the Company a real threat to their own survival ${ }^{60}$. Meanwhile, on 21 July 1321, Robert of Naples summoned all his barons from Acaya, to organize the defense of the principality beset by a combined Greek and Catalan offensive ${ }^{61}$.

However, Venice remained neutral, for her siding with the French barons would have escalated the existing antagonism and undermined Chris-

59 See THIRIET, La Romanie, pp. 155-168, and RuBIó 1 LLuCh, DOC, doc, cxxix, pp. 159-161.

60 «[P]ropter magnas persecutiones quas paciuntur a Grecis, de quibus se bono modo non possunt defendere, et ipsorum dominus de eis non videtur multum curare, nolentes exterminium substinere ultimum, deliveraverunt se penitus alio domino modo debito dare: sed cum de duobus sermo fuerit, videlicet de Catelanis morantibus in ducatu Athenarum, et comunitate Veneciarum, in nos tamen major pars, et quasi omnes, magis convenire videntur...

*Verum tamen velent isti domini de principatu, ut si Greci vel Catelani propter hoc frangerent treguam, quod communitas tenatur esse unum corpus cum istis ad defensionem ipsorum". RUBIO I LLUCH, DOC, doc. CXVII, pp. 145-146.

${ }^{61}$ Rubió t LuUch, DOC, doc, CXIX, pp. 147-148. 
tian powers vis-à-vis the Turks. Thus, when on 2 September 1324, Robert of Naples proposed to Venice an alliance against the Catalans and Byzantines ${ }^{62}$, Venice answered that she shad a truce with the Byzantine emperor and with the [Catalanl Company, on account of which she could not enter into any alliance against them ${ }^{63}$. In all, Venice maneuvered through these political crises hoping that the existing equilibrium would endure. Unfortunately, Venice was the only one to recognize the importance of her policies.

Although the doves's keenness prevailed in Venetian policies toward the East, the hawks's growls did not go unheard, having as their most eloquent exponent the person of Marino Sanudo. Renowned as a fourteenth century cartographer of the Mediterranean, Sanudo displayed an insightful understanding of the Eastern Mediterranean's political milieu. This understanding legitimized itself through the consanguineous ties Sanudo had with the duke of Andros, Marco Sanudo, with the lord of Melos, Francesco Sanudo, with the duke of Naxos, Guglielmo Sanudo, as well as with other members of this patristic family, which had extensive commercial and mercantile interests in Negroponte, Alexandria, etc. Likewise, Sanudo's network of acquaintances webbed Doge Giovanni Dandolo (1280-1289), several baiuli of Negroponte, the House of Anjou, Robert of Naples and popes Clement V (1305-1314), and John XXII (1316-1334)64.

In a letter from 1325, Sanudo reminiscently accounted to Ingerano SteIla, bishop of Capua and advisor to Robert of Naples, the ominous events of 1319 and 1320. The conquest of Neopatras and a score of other cities and castles by the Catalans in 1319, foretold the grandiose machinations and designs of the House of Aragón in the Eastern Mediterranean. By 1320, Odo de Novelles, marshal of the Catalan Company, had married the sister of Gabriel Melissenos, the Byzantine lord of Castri and Lekhonia, fueling the despondency of the Venetian lords scattered throughout Romania, for whom the Catalans meant nothing but troubles ${ }^{65}$. By March 1326, Sanudo alluded to the territorial pretenses of the House of Aragón, which, in the person of Federico of Sicily, had assumed lordship over the Company in 1312. But another intolerable characteristic of the said Company, was its amicable relations with the Turks, a group that Sanudo augured would cause in conjunction with the Catalans much hardship and sorrow to the Venetians ${ }^{66}$.

${ }^{62}$ RUaio 1 LLUCH, DOC. CXXII, pp. 150-151.

63 erespondet dominus dux quod habet treguam cum domino imperatori Grecorum et cum illis de compagna propter quas non posset facere ullam unionem contra eos $s$. RuBıo I Luch, DOC, doc, Cxvil, p. 145

64 Aldo CERLINI, aNuove Lettere fi Marino Sanudo il Vecchiow, La Bibliofilia, xLII (1940), pp. $322-323$.

65 RUBIO I LLUCH, DOC, doc. CXXIX, pp, 159-16i.

os RuBio I LluCH, DOC, doc. CXXXIII, p. 164. 
These auguries all but turned into reality as Sanudo reported the raids conducted by the Turks on Negroponte and several other islands, from which Christians were expatriated and led to servitude and slavery in Muslim lands $s^{67}$.

Sanudo's demagoguery unfolded exhilaratingly as the Crown of Aragon overwhelmingly completed her occupation of Sardinia. In this, Sanudo saw the unquestionable rise of Aragón as a force to be reckoned with if Venice and the Angevines were to preserved Romania.

[For] our lord the king [Robert of Naples] ought to know well the Catalans. how they are made like ticks, for wherever they settle they cannot be removed unless they are dead. And his magnificence well knows how much time it is since they came into Sicily, then Sardinia was given to them so that they may leave Sicily, and they hold [now]. Sardinia and Sicily, and the Duchy of Athens with a good part of the aforesaid Blachia [Thessalia]: and are they satisfied? Certainly not. Indeed, they look every day for a fictitious way and manner to transgress, so that war might occur, to have Negroponte, and if they have Negroponte, the other islands of Romania will not be able to resist not falling into their hands; and, with time, danger will increase for the island of Crete, and also Morea.... will come into their hands ${ }^{68}$.

The prophecies of Sanudo were the more nefarious when considering the strong and traditional friendship that existed between the Catalan Company and the Turks of Asia Minor. Sanudo then urgently demanded the creation of an alliance among Naples, the Papacy, the Byzantine Empire, and Venice, aimed at checking this rising threat and especially at destroying any possible contact between the Turks and the Catalans ${ }^{69}$.

Turbulent were indeed these years for the Venetians in Romania. A third treaty with the Catalans was signed in $1331^{70}$. As in 1319 and 1321 , the Venetians demanded the total demilitarization of the Catalan naval forces in the region, and in their ceasing in assisting or engaging in any piratical activities

${ }^{67}$ Rubio I Lluch, DOC, doc, cxxxvi, pp, 167-168.

of equod dominus noster Rex bene debet cognoscere Cathelanos, quantum ipsi facti sunt ut ceccha, nam ubi se ponunt non possunt extrahi nisi mortui. Et bene novit sua magnificentia quantum est quod venerunt in Sicilia, postea eis data Sardinia, ut dimitterent Siciliam, et ipsi tenent Sardiniam et Siciliam et ducatum Athenarum cum bona parte Blachie predicte; et contentatur ipsi? Certe non. Imo [sic] cotidie querunt viam et modum perforandi, ut facit terrebellum, pro habendo Nigroponte; et si habebunt Nigropontem, alie insule Romanie non poterunt resistere quod non perveniant ad manus eorum; et etiam imminetur periculum longitudine tempori insule Cretensi, nee non ct Amorea, quam tenent Latini et Greci, foret provenienda in manis eorums. CerLINI, Nuove Letlere, pp. 351-352.

${ }^{69}$ CERLINI, Nuove Lettere, p. 354.

${ }^{70}$ Thomas, DVL, doc. 108, pp. 214-219; Rubió I Luch, DOC, doc, CLII, pp. 196-200; LoENERTZ, BYZ, doc. 14, p. 140. 
in those walers. The Venetians also required that the Catalans desist from partake in any new agreement or coalition with the Turks, and from aiding or welcoming them in the duchy and their army. At the same time, the Catalans had to provide military assistance and support to the Venetians against the Turks, if these were ever to attack the island of Negroponte. Finally, the Venetians restricted the building of any new fortification in the territories of Carystos ${ }^{71}$.

The treaty of 1331 began a period of rapproachment and amicable relations between the Catalans of Athens and the Venetians. This treaty did not mark the end to all the hostilities in Romania, nor even between Venice and the Company, both of whom entered into this accord as a way to divest their attention into other areas of Romania. The Catalans were now facing a crusade preached against them by John XXII and led by Gualtier II de Brienne, claimant to the ducal throne. Gualtier, with the assistance of the Avignonese Papacy, the French barons of Acaya, and Robert of Naples, was scheming to recover the land lost by his father in $1311^{72}$. For her part, Venice was in need of addressing the rising power of the Turks and Genoese, while closer at home she had to cope with dissension among her subjects and the escalating power of Hungary. By 1332, the Catalans were fighting the forces of de Brienne, while Doge Francesco Dandolo was urging his subjects in the Levant to ally with the Byzantine Empire against the Turks ${ }^{73}$. Thus, the treaty of 1331 was not only an attempt by the Venetians and the Catalans at solving their differences, but also an impending urge to provide some peace to a region that was little by little becoming a world of anarchy and chaos.

Nevertheless, something was accomplished in the year 1331. After twenty years of worries and frantic efforts, the Venetians had neutralized any Arago-Catalan or Sicilian venture of using the Duchy of Athens as a stepping stone to the East and its markets. With the treaty of 1331 , the Catalan connection had finally been checkmated.

\section{CONCLUSIÓN}

The first three decades of Catalan presence in the Levant, were characterized by the Company's constant warfare and strife with its neighbors and masters. While some powers in the East saw their conflicts with the Cata-

71 ket Compagna tota non armabunt consencient modo aliquo vel ingenio in toto ducatu Athenarum, nec aliqua alia parte..., nec aliqua de remis tenebunt..

*Nec aliquos cursarios receptabunt, undecumque sint, modo aliquo vel ingenio in ipso toto ducatu..., nec eis prestabunt auxilium et consilium aliquod vel favorem...n. THOMAS, DVL, doc. 108, p. 215; Rubio i LluCH, DOC, doc, CliI, p. 197.

72 See Rubió I LLuCh, DOC, docs. Cl, CLI \& ClI, pp. 189-196.

${ }^{73}$ Loenertz, LG, doc. 41, pp, 215-216. 
lans as a matter of honor, patrimony or divine command, the Venetians perceived this as a struggle to preserve their economic supremacy and mercantile monopoly in Romania. The Company was not just a handful of mercenaries in need of fighting to satisfy an innate urge, as portrayed by Francisco de Moncada ${ }^{74}$; to the Venetian eye, this army was a tentacle of the Aragonese and Sicilian crowns, extending itself to grasp and choke the Serenissima's trade in the Eastern Mediterranean. As early as 1204, with the fall of Constantinople to the crusading armies, Venice had toiled to create a political environment in Romania that would have ensured her hegemonic police role in the region, while safeguarding her commercial dealings. Venice upheld this policy through the thirteenth and fourteenth centuries, making only the necessary adjustments required by the ever changing nature of the Levant's political arena.

However, by the early fourteenth century, Venice faced the continuous challenge posed by the Sicilian crown to her economic and political mastery in the East. The Catalan Company was instrumental to Sicilian expansionist policy in Romania. From 1302 to 1311, the Company remained highly autonomous in devising its own policies, but, from 1311 onward, Federico of Sicily profitably realigned the Company's endeavors along his schemes of territorial augmentation in the Eastern Mediterranean. This, to a large extent, was a prolongation of Federico's perennial quarrel with the Angevines. Nonetheless, this vendetta directly affected Venetian policy and blueprints. For one, Catalan behavior in Romania utterly shattered the status quo and balance of powers set in place by Venice. Likewise, Catalan territorial growth enhanced the commercial and trading aspirations of Aragonese, Mallorcan and Sicilian subjects, aspirations that targeted Venetian monopoly of the eastern markets. Altogether, Venice viewed the Catalan Company as a dangerous contender for her preeminent position in Romania.

Venetian responses to these challenges manifested themselves in a threefold manner. First, Venice attempted, with much success, to emasculate Catalan military might in the region. On one hand, the Serenissima mustered a considerable force to confront the Company whenever and wherever necessary. On the other, and though worthless at times, Venice exacted promises from Catalan Athens, putting an end to any understanding or cooperation between the Turks and the Company. The Venetian Commune also forced the Catalans to demilitarize their territorial holdings and navy. Secondly, the Venetian martial policy thwarted any eco-

74 [For the Catalans] were accustomed to squandering foreign property.... they plundered towns and cities that they have conquered... They decided that it was impossible to reduce themselves to living with moderationm. Francisco de MONCADA. The Catalan Chronicle, el Paso, 1975 , p. 10. 
nomic growth the Catalans might have foreseen for themselves in the region. The Catalans were unable to turn Athens into a new Barcelona, and, as indicated by Setton, «Athens had not..., like Modon and Coron, the activity of a regular stooping place for pilgrims on their way to Jerusalem nor of a depot in transit for goods passing from the islands and the mainland of the Eastern Mediterranean. The Venetians in Negroponte saw to that s 75 . Finally, as Venice achieved the economic and military weakening of Catalan Athens, she sought to integrate the Company to her preconceived status quo, as well as to channel Catalan warring behavior toward a kgood" cause, the war against the Turks. However, this aspect of Venetian response was not entirely successful. For one, Venice could not smooth the relations among the Angevines, the Byzantines and the Catalans, all of whom hated the others to death. Similarly, the Catalans did not always ascribe to the Venetian-imposed ban on all associations with the Turks. Though both Venice and Catalan Athens fought and defeated the Turks, in 1364 and 1365 respectively, this European war against the Turks was the actual product of a confrontation between Venice and the Company ${ }^{76}$.

In all, though the treaty of 1331 asserted Venetian position vis-à-vis the Catalans, it did little in bringing all European parties in Romania to an acceptable and enduring coexistence. As a matter of fact, it did not even solve all the problems upsetting Veneto-Catalan ties. For one, Carystos continued to be a discordant note in their relations. In 1360, the Serenissima claimed to have bought the city, but the Fadriques, the heirs to Alfonso and Maria, denied their ever having sold this strategic port to Venice $^{77}$. It was not until 1365 that Venice was able to occupy this disputed city in the island of Negroponte. Similarly, there were instances of Catalan piracy ${ }^{78}$, Venetian interventionism ${ }^{79}$, and the like until the final days of Catalan domination over Athens. However, if these events did not escalate into a direct or open showdown, other problems in the regions, namely the Turks, the Genoese, and the Angevines, should be held equally accountable. Veneto-Catalan relations were, after all, one small facet in the multifarious history of the Eastern Mediterranean. And though the Avignonese Papacy was clearly at odds with the Catalans, the Venetian clergy at Athens, led by archbishop Niccola Salomono (1345-1359), consistently worked to maintain a Christian unity that the rest of Europe seemed to have forgotten. Their labor contributed to a less

\footnotetext{
${ }^{75}$ Serton, Catalan Domination, p. 91

76 Serton, Catalan Domination, p. 62.

77 LOENERTZ, BYZ, doc. 44, p. 198.

${ }^{78}$ LOENERTZ, BYZ, does. 110 \& 111, p. 220; RUBIO I LLUCH, doc. CLVI, pp. 202-205.

${ }^{79}$ LoENERTZ, BYZ, doc. 77a, p. 209.
} 
antagonistic understanding between Catalan Athens and the Venetian Commune ${ }^{80}$.

In the end, the Venetians coped with the Catalans, but in doing so they proved the vulnerability of their position in the East, as well as the failure of all attempts to unite European powers in the Eastern Mediterranean.

80 The Catholic clergy at the duchy, composed mostly by Venetians, continuously attempted the reconciliation of the Company with the Avignonese Papacy. When their efforts yielded little results, the Venetian clergy, including two bishops of Thebes, Isnard and Leonardo Pisani, disregarded the existing bans of excommunication against the Catalans; Isnard went as far as to celebrate mass for the Catalans in the metropolitan church of St. Mary of Thebes. See Setron, Catalan Domination, pp. 45-49. 